University of Warwick institutional repository: http://go.warwick.ac.uk/wrap This paper is made available online in accordance with publisher policies. Please scroll down to view the document itself. Please refer to the repository record for this item and our policy information available from the repository home page for further information.

To see the final version of this paper please visit the publisher's website. Access to the published version may require a subscription.

Author(s): Michael Orton

Article Title: Inequality and the Reform of a Regressive Local Tax: The Debate in the UK

Year of publication: 2005

Link to published

version: http://dx.doi.org/10.1017/S1474746405002393

Publisher statement: None 


\section{Inequality and the Reform of a Regressive Local Tax: The Debate in the UK}

\section{Michael Orton}

Institute for Employment Research, University of Warwick

E-mail: Michael.Orton@warwick.ac.uk

The concern of this article is with the current debate about the reform of local taxation in the UK. In particular, the article examines the consideration given to issues of equity in the policy debate that has taken place through the government's 'Balance of Funding Review'. It is argued that while the outcome of the reform process remains to be seen, the current debate indicates that decisions regarding local tax will serve as an illuminating example of the extent, and limits, of New Labour policy on tax and inequality more generally.

\section{Introduction}

This article examines the current debate about the reform of local taxation in the UK. ${ }^{1}$ After a decade of relatively little interest in local taxation the issue is currently again the subject of debate, including considerable media interest, emergent protest particularly among pensioner groups, a high-level government review and a growing literature (for example see Alvanides, 2004; Muellbauer and Cameron, 2000; Kenway and Palmer, 1999). The debate has led to interest in local tax systems in other countries (for example see Loughlin and Lux, 2004; Owens, 2003; and for a more general discussion of systems of local taxation Szali and Tassonyi, 2004). However, the focus on the UK is of particular interest for two reasons. First, taxation is one of the main ways in which governments affect the well-being of citizens, but studies of welfare pay remarkably little attention to its impact (Sinfield, 2003). Council tax, the contemporary system of local taxation, ${ }^{2}$ is a regressive tax meaning that those on lower incomes spend a larger proportion of their income on the tax than do those on higher incomes. With only limited exceptions (e.g. students), council tax affects every household. Therefore, reform of local taxation has the potential to make a significant impact on the welfare of citizens and a more progressive tax system could increase the disposable income of poorer citizens. This is of particular interest given that in general terms people in receipt of Income Support/Jobseeker's Allowance receive 100 per cent council tax benefit so do not have to pay any council tax. It is those in work but on low incomes that would potentially stand to gain the most from a more progressive tax, a group who are a particular target of New Labour policy.

Second, the debate about the possible reform of council tax raises more fundamental questions about the principles underpinning the UK tax system more generally. The previous reform of local tax in the late 1980s/early 1990s formed part of a much broader readjustment of the UK tax system, the outcome of which was a shift from direct to indirect taxes and, taken in totality, a much more regressive tax system. The result has been that over the last decade payment of taxation has shifted from a roughly proportional 
distribution to a regressive one in which those on lower incomes pay a higher proportion of their income in tax than do the better off; taxation accounts for 37.9 per cent of gross income for households in the bottom quintile of the income distribution but for households in the top quintile the figure is 35.1 per cent (Lakin, 2004). However, under New Labour the UK has experienced an unusual combination of slightly rising income inequality and yet falling relative poverty, which is attributable to two trends: the gap between the very rich, particularly the richest 500,000 individuals, and the rest of the population has got wider since 1997; but, at the same time, many lower-income families have seen their incomes rise faster than the average (Brewer et al., 2004). This pattern of change is very different from that of the 1980s when incomes widened across the whole population and relative poverty rates grew rapidly.

New Labour tax and benefits policies have played a key role in current trends because if the government had simply up-rated the tax and social security system it inherited in line with inflation, the rise in inequality would have been far greater (ibid.). Local tax provides just 4 per cent of the total UK tax yield (Glennerster, 2003) so its ability to affect these trends should not be overstated. Its relevance is that in the light of New Labour's hyper-sensitivity regarding tax (Fabian Society, 2000), developments such as tax credits being 'horrendously complex' (Deacon, 2002: 109) and the characterisation of New Labour implementing taxation by 'stealth', the current debate about the reform of local tax is allowing for an open and transparent discussion of principles underpinning taxation. Thus, two questions are posed: does the current debate about local tax indicate that a more progressive system of tax may be introduced; and does the debate provide evidence of a more fundamental shift in tax policy generally?

The article will discuss local taxation since the 1980s, focusing on issues of regressivity and the relationship between systems of local tax and shifts in UK tax more generally. This involves firstly looking at the predecessor of council tax, the community charge or 'poll tax' ${ }^{3}$ as it was popularly known, and the construction of council tax. Attention then turns to the current debate about the reform of local tax, increasing concerns about the regressivity of council tax and the government's review of local government funding. Particular consideration is given to the review's approach to the principles that should underpin reform. The article concludes by arguing that equity is a key consideration in the current policy debate, which is itself a marked change from the 1980s/early 1990s. It remains to be seen what the eventual outcome of the reform process will be, but decisions regarding council tax will serve as an illuminating example of the extent, and limits, of New Labour policy on tax and inequality more generally.

\section{Local tax and regressivity}

The introduction of council tax followed the downfall of the preceding system, 'poll tax'. In order to understand the construction of council tax it is first necessary to consider poll tax.

\section{'Poll tax'}

'Poll tax' was introduced in 1989/90 and can be seen as an expression of 1980s Conservative government policies. Local taxation in the UK has been the subject of periodic crises over the last 50 years (McConnell, 1997) and 'poll tax' was in part a 
response to growing concerns about problems with the long-standing system of general rates. However, Margaret Thatcher (in)famously declared that 'poll tax' was to be her 'flagship' policy (see Butler et al., 1994). At an ideological level, 'poll tax' can be seen as an expression of a 1980s New Right conception of citizenship. 'Poll tax' was a flat-rate tax drawing on an ethos of everyone paying their 'fair share' in the name of self-reliance and accountability (Lister, 1990). 'Poll tax' even sought to replace the idea of a citizen of a community with the notion of a paying customer (ibid.) as the government argued that 'poll tax' was not actually a tax but a charge for services (Esam and Oppenheim, 1989), hence its formal title of 'community charge'.

The new tax was highly regressive and was dramatic in benefiting those with higher incomes over people on low incomes (also see Orton, 2002). The change from general rates, which was based on the individual value of properties, to the highly regressive flatrate 'poll tax' meant that households with a net income of under $£ 100$ a week lost $£ 1.30$ a week (Oppenheim, 1993). Households with a net income of $£ 200$ to $£ 250$ a week lost even more ( $£ 3.85$ a week) because rebates ran out at that stage. In contrast, households with a net income of $£ 600-£ 1,000$ a week gained $£ 4.04$. The greatest benefit was to those on the highest incomes with households that had an income of over $£ 1,000$ a week gaining $£ 6.50$ a week from the introduction of 'poll tax'. 'Poll tax' met with widespread protest and an extensive campaign of non-payment (see Hoggett and Burns, 1991-92; Lavalette and Mooney, 1990), leading to its rapid demise. In 1993 'poll tax' was replaced by council tax, to which we now turn.

\section{(De)constructing council tax}

Some of the basic features of the council tax scheme are very different to 'poll tax'. Council tax is a hybrid containing several elements (Hills and Sutherland, 1991; and see Orton, 2002) but its foundation is as a property tax not a tax on individuals as was the case with 'poll tax'. The introduction of council tax involved properties being valued and then placed in one of eight bands, $\mathrm{A}$ to $\mathrm{H}$. A different amount of tax is payable for each band with the liability for a band $\mathrm{H}$ property being three times that of a band A property. In contrast to the requirement that even the poorest had to pay 20 per cent of 'poll tax', people in receipt of Income Support/Jobseeker's Allowance are generally entitled to 100 per cent council tax benefit meaning they do not have to pay any council tax at all.

While council tax may have removed the very worst iniquities of 'poll tax', it also represented continuity in that it remained a regressive tax. The rich did lose something in the change from 'poll tax' to council tax with families in the top 30 per cent of the income distribution losing and those in the bottom 70 per cent gaining. However, the biggest gains were made in the middle of the income distribution and the overall number of winners and losers was roughly equal (Hills and Sutherland, 1991). It was noted above that the charge for a band $\mathrm{H}$ property is three times higher than for a property in band $\mathrm{A}$ a ratio of $3: 1$. If the ratio between bands had been doubled, the number of gainers would have clearly outnumbered losers with 10 per cent, not 5 per cent, losing more than $£ 5$ per week, most being in the top half of the income distribution. Therefore, changes in the construction of the council tax scheme would have altered the impact of the tax very much indeed (Kneen and Travers, 1994).

Council tax very specifically accorded with changes in income tax and national insurance rules that were implemented in the 1980s, and which placed a firm ceiling on 
the amount of tax that had to be paid by those with the highest incomes and wealth. Thus, the highest council tax band is $H$, which contains all properties valued at over $£ 320,000$ (in England). ${ }^{4}$ This means that a person may own a property worth several times more than the $£ 320,000$ starting point for band $\mathrm{H}$, but does not pay any additional council tax.

It is clear that those on lower incomes spend a greater proportion of their income on council tax than do those on higher incomes. After allowing for council tax benefit, the amount of council tax paid by people in the bottom fifth of the income distribution is 5.5 per cent of net household income, 3.5 per cent for the middle fifth, and 2 per cent for people in the top fifth (New Policy Institute, 2003). Discounting those who receive 100 per cent council tax benefit these figures become 9 per cent, 4 per cent and 2 per cent respectively.

\section{The debate about the reform of council tax}

Concerns about the regressive nature of council tax have been raised for some time (for example see Kenway and Palmer, 1999; Muellbauer and Cameron, 2000; Fabian Society, 2000) but the specific reason why council tax has begun to attract attention is because of rises in bills. Indeed, as recently as December 2001 the government rejected concerns about regressivity as being made by experts, with few complaints from taxpayers (Department for Transport, 2001). However, in 2003/2004 the average increase in council tax was 12.9 per cent (Audit Commission, 2003) with the increase in some local authority areas obviously being far higher. Rising bills have certainly been the focus of media attention (e.g. 'Labour's council tax bombshell', The Times 21 February 2003; 'Fury as councils demand huge tax increase, again', The Times 18 February 2004) and emergent protest particularly among pensioner groups (for example see the 'Is it Fair?' anti-council tax campaign at www.isitfair.co.uk). There is a particular problem for (some) older people, because pensioners' incomes generally rise more slowly than for those in work, and as a proportion of income pensioners pay nearly twice as much council tax as nonpensioners (Kenway and Pannell, 2003). However, the more general issue of regressivity does not feature so significantly in public debate: so is it one that was considered by the government's review?

\section{The 'Balance of Funding Review'}

The starting point for the review was how local government should be financed. At present council tax finances just a quarter of local authority spending, on average, with the balance met by grants from central government. Hence, the formal title of the government's examination of local government finance was the 'Balance of Funding Review' (which is abbreviated as BoF). The BoF commenced in 2003 and published its report in July 2004 (BoF, 2004). The review was chaired by the Local Government Minister and its membership included senior figures from local government, academia, business and other interested organisations. What was particularly welcome about the BoF was that its work was undertaken very openly. The review had its own website, which contains background documents such as terms of reference, membership and relevant data, plus minutes of meetings and papers presented to the review (all BoF papers referred to in this article are available at the review website - www.local.odpm.gov.uk/finance/balance.htm). This 
openness means that it is possible to gain a comprehensive understanding of the debate that is taking place.

It is important to be clear about both the scope and the limits of the BoF. The fundamental question addressed by the BoF was how local government should be financed. The review was therefore far more wide-ranging than a simple consideration of the fairness of council tax. Indeed, the review examined issues ranging from alternative systems of taxation to accountability and turnout in local elections. Where the review was more limited was that its aim was not to make detailed recommendations. Rather, it examined a range of possible options and identified 'pros and cons'. Thus, the BoF has provided an important focus for the policy debate, but it has not concluded the reform process.

For the purpose of this article what was of key interest within the BoF was the consideration given to issues of equity, regressivity and progressivity and the principles underpinning the reform debate, to which we will now turn.

\section{Principles for reform}

The breadth and complexity of the issues facing the BoF were reflected in an initial 'Issues Paper' (BoF, 2003a), and this did include regressivity. Prominence was given to issues such as 'gearing' (the term used to describe the fact that because of the high level of funding provided by central government a council which raises spending by 1 per cent, on average has to increase council tax by 4 per cent - a gearing ratio of $4: 1$ ) and the stability and predictability of the tax yield. However, a section headed 'fairness' was included, which acknowledged that council tax is regressive and posed a question for the BoF: 'Should the local tax system be more concerned with regressivity?' (ibid: 11). ${ }^{5}$

Detailed consideration of the principles to underpin reform was provided for the BoF in a paper by Stoker and Meehan (2003). The authors argue that the judgement of what makes a tax a fair or legitimate tax is a matter of political values and choices' (ibid: 4), but a key principle is that taxes must be seen as fair, justifiable and legitimate, and progressivity can be a consideration within this. The paper also provides a summary of different approaches to fairness within UK debates about local tax. While the Fabian Society Commission on Taxation and Citizenship concluded that progressivity should be a principle on which to base taxation (Fabian Society, 2000) the government's view has been framed in the more general notion that there should be fairness between those who use and pay for local services.

The first stage of the review concluded by determining criteria against which options for change would be assessed, and progressivity was identified as a criterion (BoF, 2003b). The criteria that were selected were not necessarily fixed. The BoF noted that those it had identified were not necessarily exhaustive and different criteria could be used to examine particular options, if appropriate. The selected criteria also reflected the range of concerns faced by the BoF, such as accountability and administrative ease of collection. However, progressivity was among seven key principles identified with the BoF determining that one criterion to be used in assessing possible reform was 'how far each option would relate to taxpayers' relative wealth' (ibid: paragraph 13).

The second stage of the BoF considered detailed options for change, and progressivity was certainly used as a criterion in assessing proposals. Options for change included 
expanding the number of council tax bands and increasing the rise in bills between bands, which would lead to those in higher value properties paying more, but could lead to significant regional inequity (New Policy Institute, 2004). A local income tax on the face of it offers a much more progressive form of tax, but the administrative challenges in moving to such a system are myriad. There are other specific problems, such as, if the PAYE system is used, this does not take account of income from investments (Chartered Institute for Public Finance and Accountancy, 2004) meaning the resources of some (wealthy) citizens would not be included.

In its actual report, the BoF concluded that council tax should be retained but reformed (BoF, 2004), and a further review is to take place in 2005 to examine possible reforms in more detail. The BoF report explicitly cited 'progressivity and fairness' as a key principle on which to base reform. However, the more detailed discussion was less forthright and stated only that progressivity 'might well' form part of the consideration of whether a tax is fair (ibid: 24). The final outcome of the reform process, and the prominence given to the issue of progressivity, therefore remains to be seen.

\section{Conclusion}

While the government rejected concerns about the fairness of council tax as recently as 2001, issues of equity can now be seen to be a clear part of the reform debate. The eventual outcome does, however, remain to be seen. There continue to be those who argue for a reformed system that would increase regressivity. For example, the Adam Smith Institute is advocating a local sales tax to replace council tax (Carswell, 2004). But, at the very least, the need to address the issue of regressivity is on the reform agenda.

Moreover, what of the second question posed at the start of this article - does the debate about the reform of local tax suggest a broader shift in tax policy? As noted above, the current UK tax system, when taken in totality, is highly regressive: but under New Labour there has been some shift. The 2003 increase in National Insurance and the tax credits system are indicators of this change. The debate about local tax is raising fundamental and contentious issues about tax policy more generally, including progressivity and regressivity, the contribution to be made by business and the position of the very wealthiest citizens. It is perhaps too soon to argue that a definite shift can be detected. However, the terms of the debate are certainly very different to the last reform of local tax in the UK and this is a significant shift in itself.

Just as 'poll tax' was an expression of 1980s Conservative government policies, so the outcome of the current debate will provide an insight into the principles upon which New Labour is developing its taxation policy. The decision to undertake a further review is perhaps an indication of the difficulty of the political choices faced by New Labour. What is clear is that any change in local tax has the potential to impact significantly on the welfare of citizens, and will help either challenge or entrench current inequalities. So far the debate demonstrates that the broad issue of equity is on New Labour's agenda, but the outcome of the reform of local taxation is truly in the balance - and the final result will be highly illuminating.

\section{Acknowledgement}

My thanks to the two anonymous referees for their very helpful comments. 


\section{Notes}

1 This article draws principally on a literature review undertaken as part of an ESRC funded research project entitled 'Local taxation, wealth and citizenship' (award reference RES-000-22-0597). Findings papers from the research are available at http://www2.warwick.ac.uk/fac/soc/ier/research/current/ Itwc/.

2 It should be noted that within the UK, Northern Ireland has a separate system of local tax and there are some differences in the council tax scheme in England, Scotland and Wales. The review of local government finance referred to in the article, examined only the position in England and Wales.

3 The use of the terms 'community charge' and 'poll tax' can be contentious. While the former was the proper title of the system of local taxation, it was also an ideologically loaded notion (as illustrated by Lister, 1990 and Esam and Oppenheim, 1989). The term 'poll tax' was widely adopted, and used especially in protests against the tax. It can, therefore, be viewed as inherently critical. However, as evidenced by the references below, 'poll tax' has been used in other academic studies. Taking account of these points, this article uses the phrase 'poll tax' but within inverted commas.

4 The council tax valuation bands are slightly different for England, Scotland and Wales. All are based on 1991 prices, although property revaluations are planned shortly.

5 While the concern here is with the question of equity at the level of the individual, there are two other ways in which fairness is raised within discussions of local tax. A critical point is the need for equity between areas, because, without a central mechanism for equalisation, gross inequalities could ensue between rich and poor areas (for example see New Policy Institute, 2004). There is also the much neglected, and highly contentious, issue of what proportion of funding should be borne by companies through the business rates element of local taxation (see Local Government Association, 2004; Confederation of British Industry, 2004). However, these issues go beyond the scope of this article.

\section{References}

(As noted above, all Balance of Funding Review [BoF] papers are available at www.local.odpm.gov.uk/ finance/balance.htm)

Alvanides, S. (2004), 'A decade of council tax inequities? Geographical perspectives and a research agenda', Area, 36, 1, 41-49.

Audit Commission (2003), Council Tax Increases, 2003/04, London: Audit Commission.

Balance of Funding Review (BoF) (2003a), Issues for the Review, Paper 2, April, London: Office of the Deputy Prime Minister.

Balance of Funding Review (BoF) (2003b), 'Areas for further examination', Paper 13, October, Office of the Deputy Prime Minister, London.

Balance of Funding Review (BoF) (2004), 'The Balance of Funding Review - Report', Office of the Deputy Prime Minister, London.

Brewer, M., Goodman, A., Myck, M., Shaw, J., and Shephard, A. (2004), 'Poverty and inequality in Britain: 2004', Commentary 69, Institute for Fiscal Studies, London.

Butler, D., Adonis, A., and Travers, T. (1994), Failure in British Government: The Politics of the Poll Tax, Oxford: Oxford University Press.

Carswell, D. (2004), Paying for Localism, London: Adam Smith Institute.

Chartered Institute for Public Finance and Accountancy (2004), 'Reviewing the case for a local income tax', BoF Paper (19), March, Office of the Deputy Prime Minister, London.

Confederation of British Industry (2004), 'Re-localisation of business rates', BoF Paper (18), January, Office of the Deputy Prime Minister, London.

Deacon, A. (2002), Perspectives on Welfare, Buckingham: Open University Press.

Department for Transport (2001), 'Strong local leadership - quality public services', Department for Transport, Local Government and the Regions, London.

Esam, P. and Oppenheim, C. (1989), A Charge on the Community, London: CPAG/Local Government Information Unit. 
Fabian Society (2000), Paying for Progress: A New Politics of Tax and Public Spending, London: Fabian Society.

Glennerster, H. (2003), Understanding the Finance of Welfare: What Welfare Costs and How to Pay for It, Bristol: The Policy Press.

Hills, J. and Sutherland, H. (1991), Banding, Tilting, Gearing, Gaining and Losing: An Anatomy of the Proposed Council Tax, London: Suntory-Toyota International Centre for Economics and Related Disciplines.

Hoggett, P. and Burns, D. (1991-92), 'The revenge of the poor: the anti-poll tax campaign in Britain', Critical Social Policy, 33, 11, 95-110.

Kenway, P. and Palmer, G. (1999), Council Tax: The Case for Reform, London: New Policy Institute.

Kenway, P. and Pannell, J. (2003), The Impact of Council Tax on Older People's Income, London: Help the Aged.

Kneen, P. and Travers, T. (1994), Implementing the Council Tax, London: LGC Communications/Joseph Rowntree Foundation.

Lakin, C. (2004), 'The effects of taxes and benefits on household income, 2002-03', Economic Trends, June, London: Office of National Statistics.

Lavalette, M. and Mooney, G. (1990), 'Undermining the "north-south divide"? Fighting the poll tax in Scotland, England and Wales', Critical Social Policy, 29, 10, 100-119.

Lister, R. (1990), The Exclusive Society, London: Child Poverty Action Group.

Local Government Association (2004), 'Re-localisation of non-domestic rates', BoF Paper (17), January, Office of the Deputy Prime Minister, London.

Loughlin, J. and Lux, S. (2004), 'Subnational finances in Spain: lessons for the UK?', BoF Paper (22), April, Office of the Deputy Prime Minister, London.

McConnell, A. (1997), 'The recurring crisis of local taxation in post-war Britain', Contemporary British History, 11, 3, 39-62.

Muellbauer, J. and Cameron, G. (2000), 'Five key council tax reforms and twelve reasons to enact them', New Economy, 7, 2, 88-91.

New Policy Institute (2003), Council Tax Revaluation: Coping with Regional Effects, London: New Policy Institute.

New Policy Institute (2004), 'Options for reform of council tax', BoF Paper (16), January, Office of the Deputy Prime Minister, London.

Oppenheim, C. (1993), Poverty: The Facts, London: Child Poverty Action Group.

Orton, M. (2002), 'Council Tax: who benefits?', Benefits, 10, 2, 111-115.

Owens, J. (2003), 'International comparisons', BoF Paper (5a), June, Office of the Deputy Prime Minister, London.

Sinfield, A. (2003), 'Changing Tax Welfare', a paper presented at the ESPANET conference Changing European Societies: The Role For Social Policy, Copenhagen, 13-15 November.

Stoker, G. and Meehan, E. (2003), 'Local finance: guiding principles in context', BoF Paper (6), June, Office of the Deputy Prime Minister, London.

Szalai, Á. and Tassonyi, Á.T. (2004), 'Value-based property taxation: options for Hungary', Environment and Planning C: Government and Policy, 22, 495-521. 